\title{
Friedrich Schlegel
}

\section{Seks sonetter}

Læg dig sådan, ja! Og se nu hvad jeg vil: Det er ikke så dumt! Jeg stikker min stang I dit buskads - det kaldes at "kneppe" - bang! "Men hvorfor?" Det kommer vi tilbage til.

Det gør først lidt ondt - sån er det nu engang: Det går over! Lig du kun roligt indtil Du mærker blodet synge som strengespil, Som når englebryster bli'r til himmelsk sang

Der bølgende rører verdens orer. Jep! Nu er den der! Du gynger mig i møde, Slynger dine lår omkring mig og søde

Dufte stiger op og drager mig ned. Knep! Et stød, et skrig! Et sus i de hvide ben Som nar stormen ryster abletræets gren.

Mollerdrengen korer sit maskineri, Med hullet i, op ad bakken på sin vogn, Og som en bager der skubber brød i sin ovn, Puler han den runde sten med energi.

Møllerpigen - skønt i varmen tem'lig dov'n Ser den kolde sten som gløder indeni; Hun løber ned og griber in flagranti Ynglingen hvis leg hun finder vel forvov'n.

"Hør her, min dreng!" råber hun, temmelig sur: "Hvilken utérlighed har du bedrevet! Er det sådan, du vil vise at du du'r

Til at dele min seng? Sån et svineri!” Han viser hende blot hvad der står skrevet Rundt om hullet - og hun læser rørt: "Mari”.
So liegst du gut! Gleich wird sich's prächtig zeigen, Wie klug mein Rat. Ich schiebe meinen Dicken In dein bemoostes Tor. Man nennt das "Ficken". Du fragst: warum? Davon la $\beta$ mich jetzt schweigen!

Schon seh' ich Schmerz in deinen blauen Blicken. Das geht vorbei. Du mußt zurück dich neigen, Gleich wird dein Blut dir jubeln wie die Geigen Von Engeln, welche ihre Brüste schicken

In bebender Musik zum Ohr der Welt. Famos! Du einst dich mir in bravem Schaukeln, Die Schenkel schmiegen pressend, es umgaukeln

Mich Düfte, die mich locken in die Unterwelt. Ein Stoß und Schrei! - die weißen Glieder zittern Im Kampf wie Apfelblüten in Gewittern.

Der Müllerbube schiebt hinauf zur Mühle Auf seinem Karren einen Mühlenstein, Und in die Öffnung schob er glatt hinein Sein steifes Glied und schaffte so sich Kühle.

Die blonde Müll'rin sieht's im Sonnenschein, Und trotz der unerträglich dumpfen Schwüle Läuft sie hinab, daß prüfend sie's befühle. Sie faßt und fühlt, es ist von Fleisch und Bein.

"Na hör mein Junge", ruft sie sehr brutal, "Was soll die Schweinerei mit deinem Schweif? Ist das die Prüfung, die ich dir befahl,

Ob du auch würdig wärest für mein Bett?" Doch er zeigt nur die Inschrift um den Reif, Und ach! sie liest gerührt: "Elisabeth". 
Mer end alverdens kvinder har du rykket: Du min hånd - fortrolig og pålidelig Har aldrig haft et anfald af jalousi; Er altid klar når det kommer til stykket.

Jeg hylder dig, som gamle Ovid, fordi Du rummer alle kroppe, jeg har dykket Snablen i: du som altid tager trykket Og aldrig taler om at gøre forbi.

Med dig jeg derfor kækt i mit kammer står, $\mathrm{Og}$ jeg véd at jeg aldrig forgæves gik,

Når den hvide saft skummer til herligt blår.

Og dette er da den erfaring jeg fik:

Jeg ka' drømm' om andre; men evigt består Agteskabet mellem min hånd og min pik.

Den barske ostenvind der drev mig til Rom, Gav plads for Zephyrs mere lune lyster, Og jeg hor' ikke til dem der sig bryster Af en pik der blot stritter i det blà. Som

Alle andre gor de hándfaste bryster Hos Campaniens pi'r mig varm, men ofte kom Jeg til kort - som om mit skumsprøjts hvide flom Var mindre efterspurgt pà disse kyster.

Hvilken trøst var da $\mathrm{i}$ denne drengerøv Der smøg sig om min pik og blidt tygged drøv! Ingen kvinde har slikket mit blårøde

Agern så skælvende som denne søde Knægt. O ku' jeg dvæle en men'skealder Helt tæt, min dreng, ved dine marmorbalder!
Du meine Hand bist mehr als alle Weiber, Du bist stets da, wie keine Frau erprobt, Du hast noch nie in Eifersucht getobt, Und bist auch nie zu weit, du enger Reiber.

Ovid, mein Lehrer weiland, hat dich recht gelobt, Denn du verbirgst in dir ja alle Leiber, Die ich mir wünsche. Kühler Glutvertreiber, Dir hab' ich mich für immer anverlobt.

Ich stehe stolz mit dir im Raume Und streichle meine bläulichrote Glans;

Schon quirlt sich weiß der Saft zum Schaume.

So zieh' ich aus Erfahrung die Bilanz:

Die Zweiheit freut mich nur im Wollusttraume, Sonst paart sich meine Faust mit meinem Schwanz.

Der rauhe Ost, der früh nach Rom mich jagte, Wurd dort zum Zephyr hyacinthner Lüste. Und keiner, der nur immer Mädchen küßte, Rühm seinen Schwanz, daß er im Himmel ragte.

Auch mich erregen noch die herben Brüste Kampan'scher Madchen, doch wie oft verzagte Mein Meerschaum an dem fremden Golf und klagte, Daß ohne recht Verständnis diese Küste.

Wie anders schmiegte sich der Arsch des Knaben Dem Schwanz in liebend rundlichem Gehaben! Kein Weib hat so behende mit der Zunge,

Die Eichel mir geleckt wie dieser Junge.

O könnt ich doch an deinem Marmorhintern, Mein Knabe, viele Monde überwintern! 
Nu vil jeg ha' mærker, sår og smertensbål Af de hænder som på kærtegn sig forstod: Knæk det lem, du suttede på, og som stod Rankt i din hvælving som en søjle af stål!

Fra den samme kilde som den hvide flod Der fyldte dit bæger under skrig og skrål, Skal du nu fylde med anden saft din skål Og beruse dig, denne gang, i mit blod!

Tag den skarpe pisk og den gloende tang, Slà med kraft! Giv mine nosser en gang lak! Giv med smerten en lykke af høj'ste rang!

Min stønnen er vers, omend ude af hak, Og de yderste skrig skal være den sang Hvormed din trubadur tilfreds siger tak!

Af alle de mænd som du hidtil har fryg Tet, er jeg perværst: skælv ved dette skue! Jeg strækker dine bryster ud med skrue, Og slàr så en knude på dem bag din ryg.

Dine ben skal spændes fast $i$ en bue, Dine hænder samler jeg stramt i ét ryk; Således i min magt kan du være tryg Og vis pả én ting: jeg kan mer end true.

Jeg mærker din glatte hud med dybe stik Og flænger den med kniven - kors, hvor du flæb Er! - men O hvilket paradis for min pik

Mellem disse nye varme røde læb Er! Lysten stiger i takt med din panik: Beseglet er, du mit offerdyr, din skæb
Ich flehe dich um Wunden und um Male Von deinen Händen, die mich heilig sprechen. Du sollst das Glied, das du gesaugt, zerbrechen, Das steif geragt in deine Kathedrale.

Schlürf aus den Quell, der einst in weißen Bächen In deinen Kelch gespritzt beim Bacchanale. Gieß jetzt die letzte Kraft in deine Schale, An meinem Blute magst du dich bezechen!

Nimm scharfe Peitschen und geglühte Zwingen, Schlag fester und zerquäle meine Hoden! Laß tiefsten Schmerz das höchste Glück mir bringen!

Mein Stöhnen preist dich günstiger als meine Oden, Und wenn die letzten Schreie dich umschlingen, Hörst du den Dank der seligen Rhapsoden.

Von allen Männern, die dich je bedrohten, Bin ich der Geilste. Sieh mich zitternd an. Ich zerre deine Brüste Spann für Spann Und werde sie auf deinem Rücken knoten.-

Auch deine Füße knüpfe ich daran Und binde deine weißen kleinen Pfoten, Und wenn den Leib du röchelnd mir geboten Bewunderst du in mir den starken Mann.

Und wenn du schreist, dann schlitz ich deinen runden Und weichen Leib mir auf mit kaltem Streiche, Dann saugen sich die Lippen deiner Wunden

Um meinen Schwanz, daß ich vor Lust erbleiche. Jedoch mein Glück, es reift nicht aus zu Stunden: Du riechst schon sehr, mein Opfertier, nach Leiche. 